Western University

Scholarship@Western

Western Libraries Publications

Western Libraries

2009

Information Literacy and Research-Intensive Graduate Students: Enhancing the Role of Research Librarians

Marni R. Harrington

University of Western Ontario, mharring@uwo.ca

Follow this and additional works at: https://ir.lib.uwo.ca/wlpub

Part of the Library and Information Science Commons

Citation of this paper:

Harrington, Marni R., "Information Literacy and Research-Intensive Graduate Students: Enhancing the Role of Research Librarians" (2009). Western Libraries Publications. 15.

https://ir.lib.uwo.ca/wlpub/15 


\title{
Information Literacy and Research-Intensive Graduate Students: Enhancing the Role of Research Librarians
}

\author{
MARNI R. HARRINGTON \\ The University of Western Ontario, London, Canada
}

\begin{abstract}
This article investigates how psychology graduate students find information for coursework and research, who teaches them how to find it, and whether differences emerge over the course of their graduate careers. Findings indicate that these graduate students are comfortable using campus libraries, prefer electronic resources, ask supervisors when they need assistance locating information, and have some interest in furthering their information literacy knowledge. Finally, the master's students use different information management skills than do the PhD students, as evidenced by the use of bibliographic management software. Suggestions for furthering the role of research librarians focus on being more proactive, rather than expecting students to come to librarians for assistance.
\end{abstract}

KEYWORDS information literacy, graduate students, research librarian

Information literacy is an integral component of the quest for knowledge. It includes developing a critical disposition and practical use of information technology and resources, whether in a print or electronic format. The American Library Association equates information literacy with the ability to access information effectively and efficiently, to evaluate information critically and comprehensively, and to use information accurately and creatively (ALA 1998). Thus, it has always been a critical component of life as an academic researcher. In this article, the author focuses on the information literacy skills of research-intensive graduate students, and the role of research librarians in cultivating it.

Address correspondence to Marni R. Harrington, The D.B. Weldon Library, The University of Western Ontario, London, ON, Canada N6A 3K7. E-mail: mharring@uwo.ca 
Currently, the trend in Canada, including the province of Ontario, ${ }^{1}$ is an ever-increasing graduate student enrollment in professional and research programs. Given this trend, it is essential that graduate students are proficient in finding, organizing, and storing information, not only for completion of their degree requirements, but also to succeed in securing future employment and research grants when competing with the increasing pool of qualified applicants. Librarians and library services can support this success by ensuring graduate students are information literate.

Although there is a substantial amount of research addressing information literacy and undergraduate students (Liu 2005; Lampert 2005), it is lacking for graduate students. For successful thesis work, supplemental research projects, and the eventual attainment of a faculty position, there is a need for graduate students to be comprehensive and up to date in searching the current state of the literature (Barry 1997). The development of sophisticated information literacy skills can aid them in this process. Thus, it is important that research-intensive students gain information literacy skills as they progress through their graduate career so that they can optimally access the library resources that they require for their work. Recently, a needs assessment was conducted for graduate students in the Faculties of Engineering, Health Science, Medicine and Dentistry, and Science at the University of Western Ontario (Antwi-Nsiah, Feng, Hoffmann, and Stanley 2006). Results from faculty focus groups, student focus groups, and student surveys indicated that there is a need for information literacy for graduate students in these faculties. Recommendations stemming from these findings resulted in the development and delivery of workshops for these student groups. It would be beneficial if current research was also available to determine the importance of information literacy for other research-intensive graduate students. For example, many graduate programs in psychology departments in North America are research intensive and require doctoral dissertations for degree completion (some require a master's thesis as well). In addition, most psychology department graduate programs expect students to publish additional research that is not included as thesis research. Without these publications, graduate students will not obtain employment as faculty members in research-intensive departments (or even as postdoctoral fellows).

Consequently, what is the role of the library and the librarian in the graduate student's research experience? The primary goal of this research is to investigate how psychology graduate students find and manage information for coursework and research, who teaches them how to find and manage it, and if there is a developmental trajectory of learning these skills throughout their graduate school career. Through this investigation, recommendations are made to enhance the library experience of psychology graduate students, and further develop the role of librarians and the library services they offer to support graduate student success. 


\section{METHODOLOGY}

Data were collected during the months of January and February 2007 using a survey methodology. A five-page paper survey containing fourteen quantitative items was designed to investigate how graduate students have learned to access information for coursework and research, what they access, and how they access it (see Appendix 1). The majority of questions were closedended with ordered choices. A final open-ended qualitative question offered the respondents an opportunity to provide suggestions to improve library services to assist them when using the library to find information for their coursework and research. Demographic information was also collected. In compliance with Social Sciences and Humanities Research Council Guidelines, a nonmedical research ethics protocol was completed and approved by the Faculty of Information and Media Studies Research Committee at the University of Western Ontario (Western).

\section{Participants}

The target sample consisted of graduate students enrolled in the Department of Psychology at Western. The Department of Psychology houses one of the largest graduate student populations at Western, consisting of approximately 110 students in 2007. The total number of graduate students represented a manageable population; hence, all were invited to participate (Fidzani 1998).

Two weeks after the initial group e-mail request for participation, a second and final appeal was e-mailed to the same 110 students. Upon agreeing to participate, the paper survey was delivered to the graduate students' mailboxes. The respondents were asked to return the completed survey in an enclosed, addressed envelope through the campus mail system.

\section{RESULTS AND DISCUSSION}

The survey data were compiled, coded, and entered into a database. Frequency data were generated for all questionnaire items and are presented in Appendix 2. I discuss these results according to three research themes: attitude and perceived importance of information literacy; library use behavior; and provision of information literacy instruction (Table 1). The qualitative data were organized into two emergent themes, access and instruction (Appendix 3), and are presented in connection with the defined research themes.

Thirty-six graduate students completed and returned the survey: thirteen males and twenty-three females. There were fifteen Master's students (MS), ten students enrolled in PhD year 1 or 2 , and eleven students in 
TABLE 1 Research Themes, Issues, and Associated Survey Questions

\begin{tabular}{|c|c|c|}
\hline Theme & Issue & Survey question \\
\hline \multirow{2}{*}{$\begin{array}{l}\text { 1: Attitude and perceived } \\
\text { importance of information } \\
\text { literacy for graduate } \\
\text { students }\end{array}$} & $\begin{array}{l}\text { Importance of information } \\
\text { literacy }\end{array}$ & 1,13 \\
\hline & $\begin{array}{l}\text { Perceived attitude of } \\
\text { importance of information } \\
\text { literacy for supervisors, } \\
\text { other faculty, reviewers } \\
\text { and editors }\end{array}$ & 2,3 \\
\hline \multirow{3}{*}{$\begin{array}{l}\text { 2: Library use behavior and } \\
\text { asking for help }\end{array}$} & Comfort level using libraries & 4,5 \\
\hline & Resources used & $8,10,14$ \\
\hline & Assistance sought & 7 \\
\hline \multirow[t]{2}{*}{$\begin{array}{l}\text { 3: Information literacy } \\
\text { instruction }\end{array}$} & $\begin{array}{l}\text { Perceived need of } \\
\quad \text { information literacy skills }\end{array}$ & 13 \\
\hline & $\begin{array}{l}\text { Information literacy } \\
\text { experiences }\end{array}$ & $6,9,11,12,14$ \\
\hline
\end{tabular}

PhD year 3 or above. Complete demographic information is provided in Appendix 3.

\section{Theme 1: Perceived Importance of Information Literacy}

Questions were designed to capture graduate students' attitudes toward the importance of information literacy and their perceptions of their supervisors' attitudes. All respondents agree that it is important to their instructors, supervisors, reviewers, and editors that they correctly cite all relevant articles when writing course papers, theses, and research manuscripts. However, just over 80 percent of these same students feel that it is important to exhaustively search the literature before they begin a research project. Disturbingly, 11 percent disagree and 8 percent remain neutral. Thus, even though all of the students know it is important to their supervisors and other decision makers in their field (that is, those who decide whether their manuscripts are worth publishing) that they should access, evaluate, and use information accurately for their research, they are not doing it. In addition, failing to correctly search the literature could result in spending a substantial amount of time planning and conducting research that has already been published.

Similarly, when asked about their attitudes toward information literacy instruction, just over half ( 51 percent) agree that they need formal instruction for more effective and efficient use of the library, 40 percent are neutral (do not care one way or the other), and 9 percent disagree. Clearly, as Lampert (2005) suggests, graduate students do not fully understand the importance of information literacy. There is a second possibility as well. Perret (2004) asked 
107 graduate students at the Australian National University to rate their ability to find information, and then tested them on their ability to search for it. He found that these graduate students both consistently overestimated their own skills when using the library, and believe that they do not require additional instruction. The third possibility is that graduate students may believe that it is the responsibility of their supervisors or thesis committee members to find gaps in their literature search, and this is the subject of the second theme.

\section{Theme 2: Using the Library and Asking for Help}

To understand how psychology graduate students use the library, the author explored library anxiety, the types of resources used, how resources are accessed, and where students seek assistance when using resources. All of the respondents use the main social science library on campus in some capacity. The other campus libraries are used to a lesser degree. All students surveyed are comfortable going into the libraries on campus to find resources. However, although the students are very comfortable with the library building, they are not comfortable asking for assistance from library personnel when using library resources. That is, the majority of graduate students seldom or never seek formal assistance when learning how to use library resources. Sadler and Given (2007) reported similar results on the basis of in-depth interviews with graduate students about their library use. They found that although the graduate students are aware that they can use librarians as a resource, they do not want to "go up to the resource person and ask a dumb question” (121). The University of Rochester study (Randall, Smith, Clark, and Foster 2008) also found that the graduate students they interviewed rarely ask for help from library professionals when using library resources. Instead, they prefer to rely on their own knowledge or whatever support their supervisors can provide. Thus, a second interrelated issue might be convenience. Given the fact that only 25 percent of these graduate students regularly visit the library, it may be more convenient to ask their supervisors, committee members, and fellow students for help because they have regular access to these colleagues. That is, it is possible that one reason why they do not ask librarians for assistance is because librarians are not in a physically convenient location.

Although, as previously indicated, all of the respondents physically visit the library to find resources, only 25 percent do so regularly and the majority of the information is sought electronically. All of the students reported that they retrieve library resources through the library Web page, and most often search for information through the online library catalogue ( 92 percent), and online databases (100 percent). The two databases most frequently used by this group of graduate students were PsycINFO (89 percent for coursework, 
86 percent for research) and PubMed (25 percent for coursework, 36 percent for research).

The qualitative data also support the dependence on electronic resources. For example, suggestions to improve library services and resources include increasing the number of articles, journals, and back issues that are available online. This dependence is demonstrated by suggestions such as "make more journals available online as complete PDF or html" and "more papers should be available online."

Although these results support the group's affinity toward electronic material, it does not mean they find the material in an efficient and effective manner. New York University's library study (Marcus, Covert-Vail, and Mandel 2007) gathered data through focus groups looking at the research practices of graduate students. In what researchers called the "discovery" dimension, graduate students were heavy users of the electronic collections but are not confident in their effective use of these resources and are unsure of how to get suitable assistance.

\section{Theme 3: Information Literacy Instruction}

Theme 3 questions investigated the amount of library assistance the graduate student respondents had received in the past and where they would go for assistance now if their search for course or research information was unsuccessful. For present purposes, formal information literacy instruction is defined as that provided by librarians and library staff, whereas informal instruction is provided outside of the library domain (e.g., self-taught, peers, supervisors, instructors). Interestingly, more than 80 percent reported that they have had at least one instructional experience since they started graduate school, with 36 percent receiving two sessions, and 6 percent participating in four or more sessions. Because of these experiences, it was assumed that graduate students understood the role of the library in their information gathering process. However, when asked who they approach for help finding relevant information for coursework and research, graduate students indicate that they are unlikely to approach library personnel. That is, they are most likely to ask their supervisors ( 94 percent) or peers (75 percent) for help. A distant third through fifth are faculty other than their supervisors (36 percent), a reference librarian (36 percent), and other library staff ( 8 percent). Thus, the library and its personnel are viewed as peripheral components of the students' research experience. Note that these results contrast with those of Washington-Hoagland and Clougherty (2002) who found that the 318 professional and graduate students at the University of Iowa do not rely on faculty for library information. The likely reason for the divergent results is that in many research-intensive programs, such as the 
one being studied herein, each student works closely with their supervisor, which is not the case in, for example, professional programs.

The use of information management tools are an effective and efficient way for graduate students to find, organize, and store information to support their research and coursework. Specifically, bibliographic management software can be an important organizational tool for library resources when writing research papers. A chi-square analysis comparing MS (Master's) versus PhD students was conducted to determine if Williams's (2000) developmental theory that students learn these skills as they progress through graduate school was apparent in this study. Surprisingly, it is the Master's students who are currently using these skills, not the PhD students, $\chi^{2}(1)=3.90, p<$ .05. Ten of fifteen MS students were using bibliographic software whereas only seven of twenty-one PhD students were. It was initially thought that the information literacy push in the undergraduate education of these students provided them with an opportunity to gain information management skills prior to graduate school. Further investigation, however, reveals that most have taught themselves how to use the software. Perhaps doctoral students just do not know that these tools are available or that librarians are available to support them. Or, as the University of Rochester investigators found (Randall et al., 2008), graduate students may perceive that the time needed to invest in learning to use a tool like RefWorks is a cost that does not outweigh the potential benefits.

Sabella and Tyler (2001) state that to be the best in their field, graduate students need to be current in their area of study. The use of current awareness services like electronic tables of contents or journal alerting services are excellent tools to maintain currency in an individual's research area. However, the graduate students surveyed are not taking advantage of the convenience of alerting services to keep them up to date. Surprisingly, only 11 percent of the graduate students surveyed in this study use current awareness services, and of these users, none of them learned about it through the library. University of Minnesota researchers (Marcus, Lougee, and McCready 2006) found that the science faculty at their institution claimed to rely on their graduate students to keep them current, but the graduate students worried they were missing things. Similarly, Thaxton (2002) advocates that information literacy training is important for graduate students because faculty supervisors may misjudge the ability of their graduate students to retrieve and evaluate information. Unfortunately, it appears that neither graduate students nor faculty are learning these skills from librarians.

In this survey, respondents were also asked, "Are there any ways in which you think that library services and/or resources could be improved to assist graduate students when looking for information for coursework and/or research?" The qualitative data indicate that these students want to know more about library-based services and support. As detailed in Appendix 3, there is an interest in further developing information literacy skills. 
Specifically, feedback includes learning how to use electronic tables of contents, alerting services, interlibrary loans, and reference management software as well as developing better searching skills. Student comments reflect their need to know more in the very general comments made about library services ("improve awareness of all services available") to the more specific comments about searching databases ("are there other databases I should be using more exhaustively in my searching?"). These graduate students also recognize that they need to increase their overall awareness of library resources and services to help them with their coursework and research. Interestingly, other comments from the graduate students targeted the role of the librarian:

A resource librarian could be invited to orientation or a yearly seminar to inform students of changes and new programs available (e.g., alerting systems).

Subject librarian could let more faculty know about their skills, and then faculty could encourage their students to make use of the library services.

Comments such as these suggest an interest in librarian support and a desire to expand library-related knowledge. However, these comments are inconsistent with previous quantitative data stating that information literacy skills are not important. Specifically, these students do not feel it is important to exhaustively search the literature and just over half of the respondents feel they need formal information literacy instruction. Perhaps the benefits of a research librarian who supports subject-specific, graduate level information literacy and the plethora of services available and supported by a research library need to be clearly articulated and actively established within the user community. The issue of access was also a common element in the qualitative data. Most of the suggestions concerned an increase in electronic journal access by time period, such as in "get online access to journals more distant in time" and "more years to online journals." Without the money to purchase all requested back issues, this access issue could be resolved by graduate students learning how to effectively access material we do not have (e.g., through interlibrary loan). These findings are consistent with Marcus, Cover-Vail, and Mandel (2007), who state that students regarded issues of access to be a major barrier and source of frustration when finding, storing, and organizing information.

\section{RELEVANCE TO PROFESSIONAL PRACTICE}

Academic Libraries must address the changing expectations and needs of our research-intensive graduate students. Addressing information literacy is one 
way to continue "a discourse on the role that librarians should assume in the educational spheres of instruction, curriculum and faculty development" (Ondrusek 2008, 49). Through the exploration of information literacy themes, the present study provides a snapshot of research-intensive, full-time graduate students in 2007. This section focuses on changes in professional practice to address the needs of these students, with an emphasis on understanding that they prefer using electronic resources, do not use more sophisticated library services to find, organize, and store information, and do not come to the library for resources or help with resource, but prefer to ask the people around them for help. Alternative methods of support must be created to ensure their success as research-intensive graduate students as they develop into future research-intensive faculty.

The results clearly indicate that this group prefers electronic access to resources. Although none of the students are uncomfortable using the library, they choose electronic access to sources over and above access within library facility. As one user states, "I know the resources are there, I just don't use in-person resources often." Convenience may dictate that they just do not physically enter the building, preferring to work in their offices or laboratories and asking for help there. Hence a focus on electronic books in addition to electronic journal access would be logical. Ongoing user-driven e-book trials have been popular with psychology titles at our institution, and if graduate students are not coming into the library, they can access them electronically rather than going without. Supporting a chat service presence would also provide point-of-need assistance for graduate students. The students can chat with a librarian from their office or laboratory. Because the students do not have to identify themselves, they do not have to be afraid of "asking a dumb question." Another electronic option is librarian-produced tutorials. Bianco (2005) suggests a number of ways to successfully implement tutorials with a focus on graduate students.

This research demonstrates that psychology graduate students do not like to ask for help when learning how to use resources. None of the students use alerting systems, and less than half use citation management software. The qualitative data suggest that many of these students have an interest in furthering their information literacy skills. Hence, it would be valuable to actively pursue this group of users and demonstrate library tools and services that would enhance their research and coursework through hands-on workshops and online tutorials. The workshops could address sophisticated information literacy skills relating to finding and storing information and provide point-of-need assistance and learning for graduate students.

Formally, librarians are providing some instruction as indicated by the instructional sessions graduate students attended. However, these same 
students seem to rely on their supervisors and peers for informal instruction before they turn to librarians. Because the students do not like to ask for help and are not in the library, it would be favorable to establish a physical departmental presence. This would not be a static presence that is waiting to be asked questions, but a proactive presence that participates in the graduate student learning process. Along with new graduate student orientation sessions to introduce students to the array of library resources and services, it would also be important to develop regular workshops within the department. The workshops could be integrated into the regular rotation of "brown bag" speaker series, in which many departments have a mandatory attendance policy for their graduate students. The location would be more convenient for faculty members as well. Since graduate students rely on their supervisors for guidance, faculty members should be targeted to ensure that they are aware of the library services that are available to enhance their students' research experience. Alternatively, many departments offer professional development courses for their students. Information literacy workshops geared toward research-intensive graduate students could also be developed and delivered in conjunction with these courses.

In conclusion, the essence of many of these recommendations is to alter the traditional role of librarians. A change in the physical and virtual presence of a research librarian will prove to enhance the level of information literacy knowledge of research-intensive graduate students. Specifically, rather than being a static librarian who is waiting to be asked for help, we need to be proactive, influential research librarians who are part of the graduate student experience.

\section{NOTE}

1. There is a push to double the number of graduate students enrolled in Ontario universities. The Council of Ontario Universities (COU)'s task force on graduate education is asking the Ontario government to fully fund graduate education and establish a ten-year goal to double graduate enrolment. From: http://www.cou.on.ca/content/objects/Advanced\%20degrees\%2021.pdf

\section{REFERENCES}

ALA: American Association of School Librarians and Association for Educational Communications and Technology. 1998. Information power: Building partnerships for learning. Chicago: American Library Association.

Antwi-Nsiah, F., V. Feng, K. Hoffmann, and M. Stanley. 2006. Graduate student library research skills workshop series: A needs assessment. November. https://www.lib.uwo.ca/taylor/grad/needsassessment.shtml (accessed January 6, 2008). 
Barry, C. 1997. Information skills for an electronic world: Training doctoral research students. Journal of Information Science 23: 225-38.

Bianco, C. 2005. Online tutorials: Tips from the literature. Library Philosophy and Practice 8(1) Fall. http:libr.unl.edu:2000/LPP/lppv8n1.htm (accessed July 31, 2009).

Fidzani, B. T. 1998. Information needs and information-seeking behavior of graduate students at the University of Botswana. Library Review 47: 32944.

Lampert, L. 2005. "Getting psyched" about information literacy: A successful facultylibrarian collaboration for educational psychology and counseling. The Reference Librarian 89-90: 5-23.

Liu, Z. 2005. Prints vs. electronic resources: A study of user perceptions, preferences, and uses. Information Processing \& Management 42: 583-92.

Marcus, C., L. Covert-Vail, and C. A. Mandel. 2007. NYU 21st Century Library Project: Designing a Research Library of the Future for New York University: Report of a Study of Faculty and Graduate Student Needs for Research and Teaching http://www.library.nyu.edu/about/KPLReport.pdf (accessed April 6, 2009).

Marcus, M., W. Lougee, and K. McCready. 2006. A Multi-Dimensional Framework for Academic Support: A Final Report. http://www.lib.umn.edu/ about/mellon/UMN_Multi-dimensional_Framework_Final_Report.pdf （accessed April 1, 2009).

Ondrusek, A. 2008. Information literacy. In Academic Library Research: Perspectives and Current Trends, ed. M. L. Radford and P. Snelson, 48-81. Chicago: American Library Association.

Perrett, V. 2004. Graduate information literacy skills: The 2003 ANU skills audit. The Australian Library Journal 53: 161-73.

Randall, R., J. Smith, K. Clark, and N. F. Foster. 2008. The Next Generation of Academics: A Report on a Study Conducted at the University of Rochester. September 16, 2008. https://urresearch.rochester.edu/retrieve/15430/ Report+to+Public+on+Grad+Student+User+Research.pdf (accessed March 13, 2009).

Sabella, R. A., and J. M. Tyler. 2001. School counselor technology competencies for the new millennium. In Elementary school counseling in the new millennium, ed. D. S. Sandhu, Alexandria, VA: American Counseling Association.

Sadler, E., and L. M. Given. 2007. Affordance theory: A framework for graduate students' information behavior. Journal of Documentation, 63(1): 11541.

Thaxton, L. 2002. Information dissemination and library instruction in psychology revisited: 'plus ça change...' Behavioral and Social Sciences Librarian 22: 114.

Washington-Hoagland, C., and L. Clougherty. 2002. Identifying the resource and service needs of graduate and professional students: The University of Iowa user needs of graduate professional series. Portal: Libraries and the Academy 2: $125-43$.

Williams, H.C. 2000. User education for graduate students: Never a given, and not always received. In Teaching the new library to today's users: Reaching international, minority, senior citizens, gay/lesbian, first generation, at-risk, graduate 
and returning students, and distance learners, ed. T. E. Jacobson and H. C. Williams, 145-72. New York: Neal-Schuman.

\section{APPENDIX 1. SURVEY}

\section{Information-Seeking Behavior of Graduate Students}

INTRODUCTION

Thank you very much for agreeing to answer approximately 21 questions investigating how you, as a graduate student, find information for coursework and research. The survey should take approximately 10 minutes to complete. This research has been approved by the University of Western Ontario Research and Ethics Board. All responses are confidential and will not include any identifying information. All full-time graduate students in the Department of Psychology have been invited to participate. Participation is voluntary and your decision to participate or not participate will in no way affect your grades or status at the University of Western Ontario. You may refuse to participate, refuse to answer any questions or withdraw from the survey at any time. There are no known risks or direct benefits to your participation in this study. Participating in this study does not restrict you from participating in other research. Voluntary agreement to participate in this survey is indicated by completing and submitting this questionnaire. To complete this questionnaire, please follow the instructions following each question or statement. Please keep in mind that these questions relate to your graduate career at the University of Western Ontario. Results from this survey will contribute to our understanding of what library services are required to best assist graduate students when searching for information for coursework and/or research.

Thank you very much for completing this survey.

Your contribution is very important to improving library service.

1. I feel that it is very important that I exhaustively search the literature before I start a research project. (choose one)

Strongly agree

Agree

Neutral

Disagree

Strongly disagree 
2. I feel that it is very important to my instructors and supervisors that I correctly cite all relevant articles when I write course papers, theses, or research manuscripts. (choose one)

Strongly agree

Agree

Neutral

$\square$ Disagree

Strongly disagree

3. I feel that it is very important to reviewers and editors that I correctly cite all relevant articles in my manuscripts that are submitted for publication. (choose one)

$\square$ Strongly agree

Agree

Neutral

$\square$ Disagree

Strongly disagree

4. I feel comfortable going into the libraries on campus to find resources for my studies. (choose one)

$\square$ Strongly agree

Agree

Neutral

$\square$ Disagree

Strongly disagree

5. Which libraries do you use to find information for your graduate coursework and/or research? (circle one choice for each library)

\begin{tabular}{llllll}
\hline The D. B. Weldon Library & Very often & Often & Sometimes & Seldom & Never \\
Allyn \& Betty Taylor Library & Very often & Often & Sometimes & Seldom & Never \\
Education Library & Very often & Often & Sometimes & Seldom & Never \\
Business Library & Very often & Often & Sometimes & Seldom & Never \\
Other library—please specify: & Very often & Often & Sometimes & Seldom & Never
\end{tabular}

6. How many times have you received instruction about how to use the information available to you through the library system at the University of Western Ontario since you began your graduate studies in the Department of Psychology?
$\square 0$
$\square 1$
$\square 2$
$\square 3$
$\square 4+$ 
7. How often have you used each of the following services when you were learning how to use the information available in and through the libraries at the University of Western Ontario? (circle one choice for each service)

\begin{tabular}{|c|c|c|c|c|c|}
\hline Library classes given by librarians & Very often & Often & Sometimes & Seldom & Never \\
\hline $\begin{array}{l}\text { One-on-one instruction from a } \\
\text { librarian by appointment }\end{array}$ & Very often & Often & Sometimes & Seldom & Never \\
\hline $\begin{array}{l}\text { Assistance from librarians via chat } \\
\text { reference }\end{array}$ & Very often & Often & Sometimes & Seldom & Never \\
\hline $\begin{array}{l}\text { Assistance from library staff at a } \\
\text { workstation or reference } \\
\text { desk/counter }\end{array}$ & Very often & Often & Sometimes & Seldom & Never \\
\hline $\begin{array}{l}\text { Assistance via e-mail from library } \\
\text { staff }\end{array}$ & Very often & Often & Sometimes & Seldom & Never \\
\hline $\begin{array}{l}\text { Online help for the library } \\
\text { catalogue (via the belp button or } \\
\text { the help with searching link) }\end{array}$ & Very often & Often & Sometimes & Seldom & Never \\
\hline $\begin{array}{l}\text { Online help for library databases } \\
\text { (e.g., PsycINFO) }\end{array}$ & Very often & Often & Sometimes & Seldom & Never \\
\hline $\begin{array}{l}\text { Online tutorials within databases } \\
\text { (e.g., PsycINFO, PubMed) }\end{array}$ & Very often & Often & Sometimes & Seldom & Never \\
\hline $\begin{array}{l}\text { Print/online guides for library and } \\
\text { Web resources in a specific } \\
\text { subject area or for a specific } \\
\text { course (e.g., Resources by } \\
\text { Subject-Social } \\
\text { Science-Psychology) }\end{array}$ & Very often & Often & Sometimes & Seldom & Never \\
\hline
\end{tabular}

8. How often do you use the following sources to locate relevant information for your coursework and/or research? (circle one choice for each source)

\begin{tabular}{|c|c|c|c|c|c|}
\hline Online library catalogue & Very often & Often & Sometimes & Seldom & Never \\
\hline Reference librarian & Very often & Often & Sometimes & Seldom & Never \\
\hline $\begin{array}{l}\text { Browsing shelves for } \\
\text { books }\end{array}$ & Very often & Often & Sometimes & Seldom & Never \\
\hline $\begin{array}{l}\text { Scanning journal titles in } \\
\text { print in the library }\end{array}$ & Very often & Often & Sometimes & Seldom & Never \\
\hline $\begin{array}{l}\text { Scanning online journal } \\
\text { titles (e.g., electronic } \\
\text { table of contents) }\end{array}$ & Very often & Often & Sometimes & Seldom & Never \\
\hline $\begin{array}{l}\text { Searching online databases } \\
\text { (e.g., PsycINFO, } \\
\text { PubMed) }\end{array}$ & Very often & Often & Sometimes & Seldom & Never \\
\hline Peers & Very often & Often & Sometimes & Seldom & Never \\
\hline Supervisor & Very often & Often & Sometimes & Seldom & Never \\
\hline Thesis committee member & Very often & Often & Sometimes & Seldom & Never \\
\hline Other faculty & Very often & Often & Sometimes & Seldom & Never \\
\hline Other (please specify): & Very often & Often & Sometimes & Seldom & Never \\
\hline
\end{tabular}

9. When you need help finding relevant information for your coursework and/or research, who do you approach for assistance? (you may select more than one option if appropriate) 
Reference librarian

Other library staff

Peers

Supervisor

Thesis committee member

Other faculty

Other (please specify):

10. When looking for information for coursework and/or research. ... (circle one choice for each question)

\begin{tabular}{|c|c|c|c|c|c|}
\hline $\begin{array}{l}\text { how often do you use library } \\
\text { resources by visiting the } \\
\text { library in person? }\end{array}$ & Very often & Often & Sometimes & Seldom & Never \\
\hline $\begin{array}{l}\text { how often do you access } \\
\text { library resources through a } \\
\text { library Web page? }\end{array}$ & Very often & Often & Sometimes & Seldom & Never \\
\hline how often do you use Yahoo? & Very often & Often & Sometimes & Seldom & Never \\
\hline $\begin{array}{l}\text { how often do you use Google } \\
\text { or Google Scholar? }\end{array}$ & Very often & Often & Sometimes & Seldom & Never \\
\hline $\begin{array}{l}\text { how often do you use other } \\
\text { nonlibrary gateways/portals? } \\
\text { (not Yahoo or Google) } \\
\text { Name of gateway/portal(s): }\end{array}$ & Very often & Often & Sometimes & Seldom & Never \\
\hline
\end{tabular}

11. Do you use software to manage your citations (e.g., Endnote, ProCite, RefWorks)?

$\square$ Yes $\square$ No

$\rightarrow$ If yes, please list the name(s) of the software that you use:

$\rightarrow$ If yes, how did you learn how to use this software: (you may select more than one option if appropriate)
$\square$ Self-taught
$\square$ Library session at UWO
Library session at other university
Peers
Supervisor
Thesis committee member
Other faculty
Other (please specify):

12. Do you currently use an electronic alerting service to inform you about updates on research topics (e.g., journal issue alerts, search alerts)?

Yes $\square$ No

$\rightarrow$ If yes, how did you learn how to use this system: (you may select more than one option if appropriate) 
Self-taught

Library session at UWO

Library session at other university

Peers

Supervisor

Thesis committee member

Other faculty

Other (please specify):

13. I feel that for more effective and efficient use of the library, graduate students need instruction on how to find information available in their subject area for coursework and/or research. (please select one)

$\square$ Strongly agree

$\square$ Agree

$\square$ Neutral

Disagree

Strongly disagree

14. What databases do you use to find information for coursework and/or research (e.g., PsycINFO, PubMed)?

\begin{tabular}{l|l}
\hline Coursework: & Research: \\
\hline & \\
\hline & \\
\hline & \\
\hline & \\
\hline
\end{tabular}

15. Are there any ways in which you think that library services and/or resources could be improved to assist graduate students when looking for information for coursework and/or research?

\section{Background information: (please select one for each)}

16. Gender

Male

$\square$ Female

17. Age

$\square 20-30$

$31-35$ 

$36-40$
$\square 41+$

18. International student
$\square$ Yes
$\square$ No

19. Enrollment status

$\square$ Full-time

$\square$ Part-time

20. Year of study
MSc1
MSc2
$\mathrm{MSc} 3$
$\square \mathrm{PhD} 1$
$\square \mathrm{PhD} 2$
$\mathrm{PhD} 3$
PhD4
$\square$ PhD5 and above

21. Area of study

$\square$ Behavioral \& Cognitive Neuroscience

$\square$ Clinical

Cognition \& Perception

$\square$ Social

Personality \& Measurement

Developmental

Industrial/Organizational

Thank you very much for completing this survey.

Your contribution is very important to improving library services.

APPENDIX 2. DESCRIPTIVE STATISTICS: FREQUENCY RESULTS

Demographic Information

\begin{tabular}{lcr}
\hline Gender & Frequency & Percent \\
\hline Male & 13 & 36.1 \\
Female & 23 & 63.9 \\
Total & 36 & 100.0 \\
\hline
\end{tabular}

$100 \%$ full-time enrolment. 
Theme 1: Attitude and perceived importance of information literacy for graduate students

Importance of Information Literacy for Graduate Students

Q1: I feel that it is very important that I exhaustively search the literature before I start a research project. (choose one)

\begin{tabular}{lcccc}
\hline & Frequency & Percent & Valid percent & $\begin{array}{c}\text { Cumulative } \\
\text { percent }\end{array}$ \\
\hline Strongly agree & 13 & 36.1 & 36.1 & 36.1 \\
Agree & 16 & 44.4 & 44.4 & $\mathbf{8 0 . 6}$ \\
Neutral & 3 & 8.3 & 8.3 & 88.9 \\
Disagree & 4 & 11.1 & 11.1 & 100.0 \\
Total & 36 & 100.0 & 100.0 & \\
\hline
\end{tabular}

Q13: I feel that for more effective and efficient use of the library, graduate students need instruction on how to find information available in their subject area for coursework and/or research. (please select one)

\begin{tabular}{lcccc}
\hline & Frequency & Percent & Valid percent & $\begin{array}{c}\text { Cumulative } \\
\text { percent }\end{array}$ \\
\hline Strongly agree & 5 & 13.9 & 14.3 & 14.3 \\
Agree & 13 & 36.1 & 37.1 & $\mathbf{5 1 . 4}$ \\
Neutral & 14 & 38.9 & 40.0 & 91.4 \\
Disagree & 3 & 8.3 & 8.6 & 100.0 \\
Total & 35 & 97.2 & 100.0 & \\
Missing & 1 & 2.8 & & \\
$\quad$ Total & 36 & 100.0 & & \\
\hline
\end{tabular}

Perceived Importance of Information Literacy for Instructors, Supervisors, Reviewers \& Editors

Q2: I feel that it is very important to my instructors and supervisors that I correctly cite all relevant articles when I write course papers, theses, or research manuscripts. (choose one)

\begin{tabular}{lcccc}
\hline & Frequency & Percent & Valid percent & $\begin{array}{c}\text { Cumulative } \\
\text { percent }\end{array}$ \\
\hline Strongly agree & 28 & 77.8 & 77.8 & 77.8 \\
Agree & 8 & 22.2 & 22.2 & $\mathbf{1 0 0 . 0}$ \\
Total & 36 & 100.0 & 100.0 & \\
\hline
\end{tabular}

Q3: I feel that it is very important to reviewers and editors that I correctly cite all relevant articles in my manuscripts that are submitted for publication. (choose one)

\begin{tabular}{lcccc}
\hline & Frequency & Percent & Valid percent & $\begin{array}{c}\text { Cumulative } \\
\text { percent }\end{array}$ \\
\hline Strongly agree & 32 & 88.9 & 88.9 & 88.9 \\
Agree & 4 & 11.1 & 11.1 & $\mathbf{1 0 0 . 0}$ \\
Total & 36 & 100.0 & 100.0 & \\
\hline
\end{tabular}


Theme 2: Library use behavior and asking for belp

Comfort Level Using Libraries

Q4: I feel comfortable going into the libraries on campus to find resources for my studies. (choose one)

\begin{tabular}{lcccc}
\hline & Frequency & Percent & Valid percent & $\begin{array}{c}\text { Cumulative } \\
\text { percent }\end{array}$ \\
\hline Strongly agree & 15 & 41.7 & 41.7 & 41.7 \\
Agree & 16 & 44.4 & 44.4 & $\mathbf{8 6 . 1}$ \\
Neutral & 5 & 13.9 & 13.9 & 100.0 \\
Total & 36 & 100.0 & 100.0 & \\
\hline
\end{tabular}

Q5: Which libraries do you use to find information for your graduate coursework and/or research? (circle one choice for each library)

\begin{tabular}{lccccc}
\hline Library name/(n = ?) & Very often & Often & Sometimes & Seldom & Never \\
\hline The D. B. Weldon Library (36) & $61 \%$ & $22 \%$ & $14 \%$ & $3 \%$ & 0 \\
Allyn \& Betty Taylor Library (36) & $11 \%$ & $11 \%$ & $47 \%$ & $17 \%$ & $14 \%$ \\
Education Library (36) & 0 & $2.8 \%$ & $11 \%$ & $36 \%$ & $47 \%$ \\
Business Library (36) & $5.6 \%$ & $5.6 \%$ & $2.8 \%$ & $2.8 \%$ & 81 \\
Kings (1) & $2.8 \%$ & 0 & 0 & 0 & 0 \\
Huron (5) & $13.9 \%$ & 0 & 0 & 0 & 0 \\
\hline
\end{tabular}

\section{Use of Library Assistance}

Q7: How often have you used each of the following services when you were learning how to use the information available in and through the libraries at the University of Western Ontario? (circle one choice for each service)

\begin{tabular}{|c|c|c|c|c|c|}
\hline Service & $\begin{array}{l}\text { Very } \\
\text { often }\end{array}$ & Often & Sometimes & Seldom & Never \\
\hline $\begin{array}{l}\text { 1. Library classes given by librarians } \\
(\mathrm{n}=36)\end{array}$ & 5.6 & 0 & 25 & 22.2 & 44.4 \\
\hline $\begin{array}{l}\text { 2. One-on-one instruction from a librarian } \\
\text { by appointment }\end{array}$ & 0 & 0 & 2.8 & 11.1 & 86.1 \\
\hline $\begin{array}{l}\text { 3. Assistance from librarians via chat } \\
\text { reference }\end{array}$ & 0 & 0 & 5.6 & 13.9 & 80.6 \\
\hline $\begin{array}{l}\text { 4. Assistance from library staff at a } \\
\text { workstation or reference desk/counter }\end{array}$ & 2.8 & 13.9 & 47.2 & 22.2 & 13.9 \\
\hline 5. Assistance via e-mail from library staff & 0 & 0 & 11.1 & 25 & 63.9 \\
\hline $\begin{array}{l}\text { 6. Online help for the library catalogue (via } \\
\text { the help button or the help with searching } \\
\text { link) }\end{array}$ & 0 & 2.8 & 25 & 16.7 & 55.6 \\
\hline $\begin{array}{l}\text { 7. Online help for library databases (e.g., } \\
\text { PsycINFO) }\end{array}$ & 11.1 & 0 & 5.6 & 22.2 & 61.1 \\
\hline $\begin{array}{l}\text { 8. Online tutorials within databases (e.g., } \\
\text { PsycINFO, PubMed) }\end{array}$ & 0 & 0 & 5.6 & 16.7 & 77.8 \\
\hline $\begin{array}{l}\text { 9. Print/online guides for library and Web } \\
\text { resources in a specific subject area or for a } \\
\text { specific course (e.g., Resources by } \\
\text { Subject-Social Science-Psychology) }\end{array}$ & 0 & 2.8 & 8.3 & 19.4 & 69.4 \\
\hline
\end{tabular}


Use of Sources

Q8: How often do you use the following sources to locate relevant information for your coursework and/or research? (circle one choice for each source)

\begin{tabular}{|c|c|c|c|c|c|}
\hline Information Sources & Very often & Often & Sometimes & Seldom & Never \\
\hline $\begin{array}{l}\text { 1. Online library } \\
\text { catalogue }\end{array}$ & 91.7 & 5.6 & 2.8 & 0 & 0 \\
\hline 2. Reference librarian & 0 & 2.8 & 8.3 & 55.6 & 33.3 \\
\hline $\begin{array}{l}\text { 3. Browsing shelves for } \\
\text { books }\end{array}$ & 0 & 5.6 & 25 & 30.6 & 38.9 \\
\hline $\begin{array}{l}\text { 4. Scanning journal titles in } \\
\text { the library }\end{array}$ & 0 & 2.8 & 11.1 & 33.3 & 52.8 \\
\hline $\begin{array}{l}\text { 5. Scanning online journal } \\
\text { titles (e.g., electronic } \\
\text { table of contents) }\end{array}$ & 16.7 & 11.1 & 36.1 & 19.4 & 16.7 \\
\hline $\begin{array}{l}\text { 6. Searching online } \\
\text { databases (e.g., } \\
\text { PsycINFO, PubMed) }\end{array}$ & 100 & 0 & 0 & 0 & 0 \\
\hline 7. Peers & 5.6 & 25 & 41.7 & 16.7 & 11.1 \\
\hline 8. Supervisor ( $58 \%$ often) & 11.1 & 47.2 & 36.1 & 5.6 & 0 \\
\hline $\begin{array}{l}\text { 9. Thesis committee } \\
\text { member }\end{array}$ & 0 & 5.6 & 30.6 & 38.9 & 22.2 \\
\hline 10. Other faculty & 0 & 8.3 & 41.7 & 27.8 & 22.2 \\
\hline 11. Google Scholar $(\mathrm{n}=2)$ & 2.8 & 2.8 & 0 & 0 & 0 \\
\hline $\begin{array}{l}\text { 12. Sources cited elsewhere } \\
(n=5)\end{array}$ & 8.3 & 2.8 & 2.8 & 0 & 0 \\
\hline
\end{tabular}

Use of Electronic versus Physical Resources

Q10: When looking for information for coursework and/or research .... (circle one choice for each question)

\begin{tabular}{lccccc}
\hline $\begin{array}{l}\text { Virtual (V) vs. Physical } \\
\text { (P) resources }\end{array}$ & Very often & Often & Sometimes & Seldom & Never \\
\hline $\begin{array}{l}\text { 1. how often do you } \\
\text { use library resources } \\
\text { by visiting the library } \\
\text { in person? (P) }\end{array}$ & $\mathbf{0}$ & $\mathbf{2 5}$ & $\mathbf{4 1 . 7}$ & $\mathbf{3 3 . 3}$ & $\mathbf{0}$ \\
$\begin{array}{l}\text { 2. how often do you } \\
\text { access library } \\
\text { resources through a } \\
\text { library Web page? (V) }\end{array}$ & $\mathbf{9 1 . 7}$ & $\mathbf{5 . 6}$ & $\mathbf{2 . 8}$ & $\mathbf{0}$ & $\mathbf{0}$ \\
$\begin{array}{l}\text { 3. how often do you use } \\
\text { Yahoo? (V) }\end{array}$ & 2.8 & 2.8 & 5.6 & 19.4 & 69.4 \\
$\begin{array}{l}\text { 4. how often do you use } \\
\text { Google or Google }\end{array}$ & 31.6 & 22.2 & 33.3 & 8.3 & 0 \\
$\begin{array}{l}\text { Scholar? (V) } \\
\text { 5. how often do you use } \\
\text { other nonlibrary } \\
\text { gateways/portals (not }\end{array}$ & 5.6 & 0 & 8.3 & 8.3 & 58.3 \\
$\begin{array}{l}\text { Yahoo or Google)? (V) } \\
\text { (n = 29) }\end{array}$ & & & & \\
\hline
\end{tabular}


Theme 3: Information Literacy Instruction

Recognized, Formal Instructional Literacy Training

Q6: How many times have you received instruction about how to use the information available to you through the library system at the University of Western Ontario since you began your graduate studies in the Department of Psychology?

\begin{tabular}{lcccc}
\hline $\begin{array}{l}\text { No. of instructional } \\
\text { sessions at UWO }\end{array}$ & Frequency & Percent & $\begin{array}{c}\text { Valid } \\
\text { percent }\end{array}$ & $\begin{array}{c}\text { Cumulative } \\
\text { percent }\end{array}$ \\
\hline 0 & 7 & 19.4 & 19.4 & 19.4 \\
1 & 14 & 38.9 & 38.9 & 58.3 \\
2 & 13 & 36.1 & 36.1 & 94.4 \\
$4+$ & 2 & 5.6 & 5.6 & 100.0 \\
Total & 36 & 100.0 & 100.0 & YES $=\mathbf{8 0 . 6 \%}$ \\
& & & & NO $=\mathbf{1 9 . 4 \%}$ \\
\hline
\end{tabular}

Provision of Instruction (Formal(f) versus Informal(i))

Q9: When you need help finding relevant information for your coursework and/or research, who do you approach for assistance? (you may select more than one option if appropriate)

\begin{tabular}{lcc}
\hline Source & $\mathrm{n}$ & $\%$ \\
\hline 1. Reference librarian (f) & 13 & 36.1 \\
2. Other library staff (f) & 3 & 8.3 \\
3. Peers(informal) & 27 & $\mathbf{9 5}$ \\
4. Supervisor (i) & $\mathbf{3 4}$ & $\mathbf{9 4 . 4}$ \\
5. Thesis committee member (i) & 3 & 8.3 \\
6. Other faculty (i) & 13 & 36.1 \\
\hline
\end{tabular}

Other Instructional Literacy Skills and Where Learned: (Formal versus Informal)

Q11.1: Do you use software to manage your citations (e.g., Endnote, ProCite, RefWorks)?

\begin{tabular}{ccccc}
\hline & Frequency & Percent & Valid percent & $\begin{array}{c}\text { Cumulative } \\
\text { percent }\end{array}$ \\
\hline Valid & & & & 52.8 \\
No & 19 & 52.8 & 52.8 & 100.0 \\
Yes & $\mathbf{1 7}$ & $\mathbf{4 7 . 2}$ & 47.2 & \\
Total & 36 & 100.0 & 100.0 & \\
\hline
\end{tabular}


Q11.3: If yes, how did you learn how to use this software? (you may select more than one option if appropriate)

\begin{tabular}{lcc}
\hline Source & n (of 17) & $\%$ \\
\hline 1. Self-taught (i) & 14 & 38.9 \\
2. Library session at UWO (f) & 5 & 13.9 \\
3. Library session at other university (f) & 0 & 0 \\
4. Peers (i) & 2 & 5.6 \\
5. Supervisor (i) & 3 & 8.3 \\
6. Thesis committee member (i) & 0 & 0 \\
7. Other faculty (i) & 0 & 0 \\
\hline
\end{tabular}

Q12.1: Do you currently use an electronic alerting service to inform you about updates on research topics (e.g., journal issue alerts, search alerts)?

\begin{tabular}{lcccc}
\hline & Frequency & Percent & Valid percent & $\begin{array}{c}\text { Cumulative } \\
\text { percent }\end{array}$ \\
\hline Valid & & & & 88.6 \\
No & 31 & $\mathbf{8 6 . 1}$ & 88.6 & 100.0 \\
Yes & 4 & 11.1 & 11.4 & \\
Total & 35 & 97.2 & 100.0 & \\
Missing & 1 & 2.8 & & \\
System & 36 & 100.0 & & \\
Total & & & \\
\hline
\end{tabular}

Q12.3: If yes, how did you learn how to use this system? (you may select more than one option if appropriate)

\begin{tabular}{lcc}
\hline Source & n (of 4) & $\%$ \\
\hline 1. Self-taught (i) & 3 & 8.3 \\
2. Library session at UWO (f) & 0 & 0 \\
3. Library session at other university (f) & 1 & 2.8 \\
4. Peers (i) & 1 & 2.8 \\
5. Supervisor (i) & 0 & 0 \\
6. Thesis committee member (i) & 0 & 5.6 \\
7. Other faculty (i) & 2 & \\
\hline
\end{tabular}




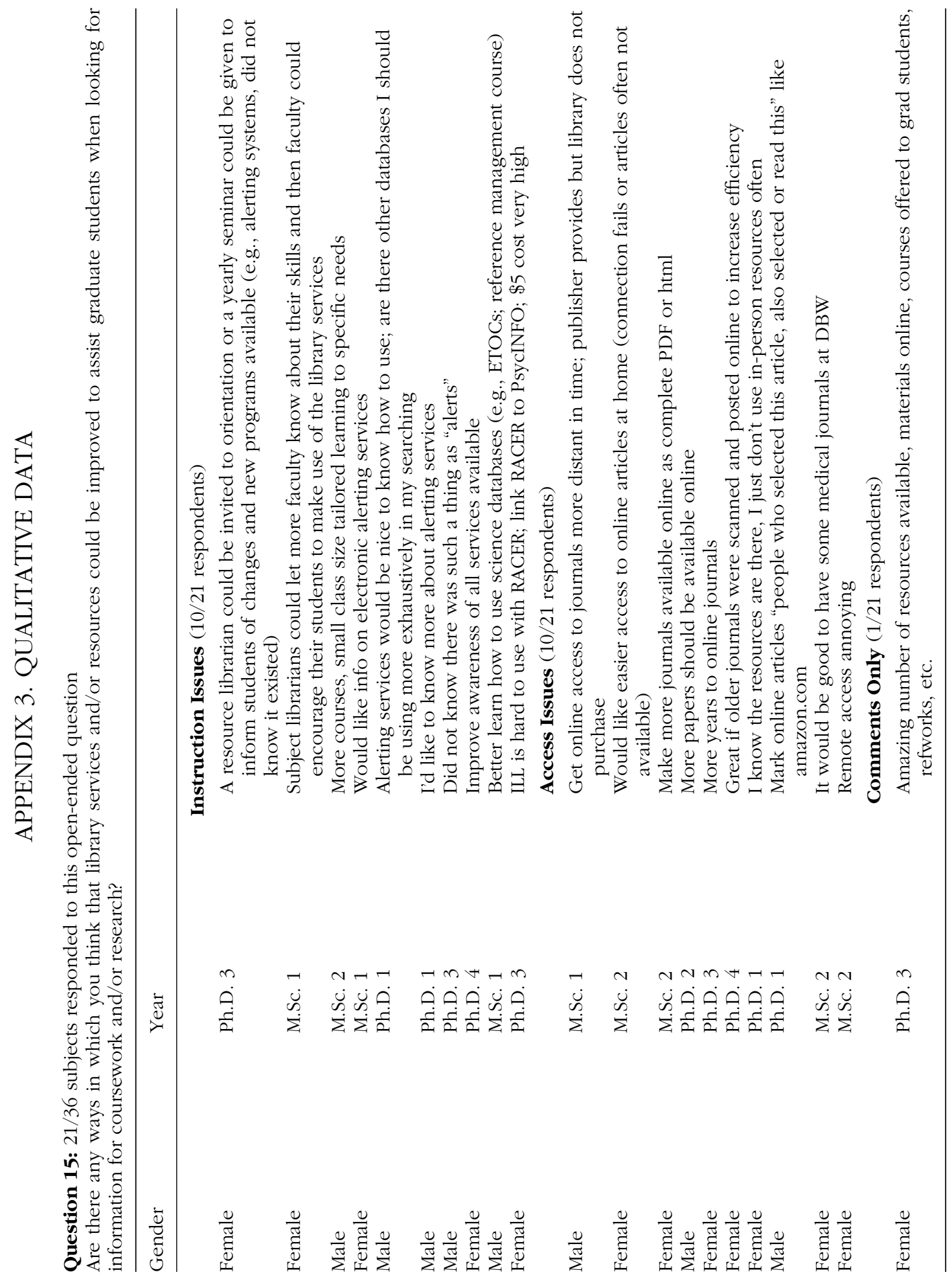

